\title{
Nationalism, Authoritarianism and Cultural Construction: Carlos Chávez and Mexican Music (1921-1952) ${ }^{1}$
}

\section{LUIS VELASCO PUFLEAU}

Translated by Silvio J. dos Santos

Art is a human phenomenon, which the state must promote and use as a weapon to educate the proletarian class.

$$
\text { Carlos Chávez (1934) }
$$

The musical nationalism in post-revolutionary Mexico was a complex phenomenon that resists a simplistic or historicist view. Its analysis requires a multidisciplinary perspective, sometimes historical, political, sociological, ideological, and musical. This article examines the notion of musical nationalism between 1916 and 1949 from the perspective of the ideological transformations of its most significant institutional protagonist, the composer Carlos Chávez (1899-1978), and his interaction with the postrevolutionary Mexican regime. The political, sociological, and aesthetic ideas of Chávez are documented in his extensive journalistic and theoretical writings, as well as his correspondence. Through the contextualization of these writings it is possible to retrace the strategies Chávez used to legitimate his positions within the Mexican musical environment and explain the process through which he became the official composer of the post-revolutionary regime. The notions of race, nationalism, cultural evolution, aesthetic education, and Mexican music, among others, are determinant factors for the comprehension of Chávez's conception of nationalism and the aesthetic development of his work. Additionally, outside the country's border, the role of American music societies [medio musical], particularly the activities of the International Composers' Guild, was decisive for the legitimization of Carlos Chávez's musical persona within Mexico. An analysis that takes into consideration all of these factors is not only pertinent but also necessary for the aesthetic and political study of the process of cultural construction in post-revolutionary Mexico, as well as the role that institutions exerted in controlling national artistic production. This study reevaluates the mechanisms of symbolic legitimation of the authoritarian regime in post-revolutionary Mexico, as well as the relationship between authoritarianism, nationalism, cultural construction, and musical creation.

\section{Revolution and Nation Building}

The socio-political and cultural life of Mexico in the first half of the twentieth century was profoundly marked by the consequences of the Mexican Revolution (1910-20). The main objectives of the Revolution were to end the dictatorship of Porfirio Díaz (1830-1915), to obtain agricultural and social justice-by means of long-sought agricultural reform—and to establish the Mexican nation. However, the much-desired nation existed only in the political imagination of the intellectual elite, especially because

\footnotetext{
${ }^{1}$ This article was originally published in Spanish in Music and Dictatorship in Europe and Latin America, ed. Roberto Illiano and Massimiliano Sala (Turnhout: Brepols, 2009), 707-30.
} 
Mexico did not have a cultural, linguistic, political, sociological, and economic unity that would allow the federation of this new nation. ${ }^{2}$ The top priorities of the post-revolutionary regime were the construction of a national cultural identity and the institutionalization of a nationalist discourse in the arts that was compatible with its political legitimacy as well as with the stability of the regime within and outside the country. This regime, "which intended to integrate a population that had been excluded from the development models prior to the revolution, was authentically popular." Once the revolution was institutionalized, however, the promises of agricultural and social justice were forgotten, leaving in place many of the socio-economic structures from the colonial period (latifundia, oligarchy, cacique [literally, "native chief," but also "local political boss"], and so on) as well as a cultural hegemony comparable to that imposed by the Spanish invaders centuries before. The fundamental difference between the cultural hegemony of the colonial period and the one imposed in the post-revolutionary period was the belief of belonging to an ancient nation that would occupy a seminal place in Western modernity through the radical changes produced by the Revolution.

The analysis of the interaction between the post-revolutionary musical institutions and the Mexican authoritarian regime ${ }^{4}$ reveals the process of identity construction and political legitimation of a postcolonial country ravaged by ten years of civil war. In order to understand the complexity of this process, it is necessary to address the construction of a Mexican national identity and its manifestations in art from a political perspective. The main objective of the nationalist discourse in the arts was to contribute to the creation of a common symbolic system for all Mexicans, a new national culture with which citizens could identify themselves regardless of their ethnic or social origin. This cultural construction was accompanied by the establishment of new political structures and institutions that allowed the populist regime to assert authoritarian powers and ensure its continuity. Indeed, the political instability during the early post-revolutionary governments (1920-34), characterized by a succession of political leaders and warlords, created a pseudo-democratic regime of a corporatist type from 1934 on, which allowed a single political party (the Partido Revolucionario Institucional [PRI]) to remain in power for over seven decades. ${ }^{5}$ Although economical, sociological, and political factors contributed to this political stability, the relationship between art institutions and the state reveals coherent and incoherent aspects in the discourses and mechanisms by which the authoritarian regime sought to legitimize its power on a symbolic level.

\footnotetext{
Many of the ideas exposed in this article were presented and developed during the International Conference "State Music and Dictatorship" (Paris, May 2009), organized by the Centre de Recherches sur les Arts et le Langage (CRAL - EHESS / CNRS), under the scientific direction of Esteban Buch, Igor Contreras, and Manuel Denis Silva. In addition to thanking the organizing committee of the conference and its participants, I would like to thank Olga Picún, Mónica Velasco Pufleau, Pierre Morel, and Jessica Garza for their comments on the final version of this article.

${ }^{2}$ Mexico is a multicultural and multiethnic [pluriétnico] country, currently comprising 52 ethnicities, in which two civilizations coexist: the Mesoamerican and the Western. See the National Commission for the Development of the Indigenous People (CDI), <http://www.cdi.gob.mx>. See also Guillermo Bonfil Batalla, México profundo: una civilización negada (Mexico, D.F.: Secretaría de Educación Pública-CIESAS, 1987).

${ }^{3}$ Ilán Bizberg, "Auge y decadencia del corporativismo," in Una historia contemporánea de México, vol. 1: Transformaciones y permanencias, ed. Ilán Bizberg and Lorenzo Meyer (Mexico: Océano, 2003), 314.

${ }^{4}$ In order to promote the notion of the Mexican post-revolutionary regime as an authoritarian political regime, I base my argument on Juan Linz's understanding of authoritarian regimes as: “. . political systems with limited, not responsible, political pluralism, without elaborate and guiding ideology, but with distinctive mentalities, without extensive nor intensive political mobilization, except at some points in their development, and in which a leader or occasionally a small group exercises power within formally ill-defined limits but actually quite predictable ones." Totalitarian and Authoritarian Regimes (Boulder: Lynne Rienner Publishers, 2000), 159.

${ }^{5}$ The PRI held power until the year 2000, when it lost the elections to the Partido Acción Nacional (PAN). For an analysis of corporatism in the Mexican regime, see Bizberg, "Auge y decadencia del corporativismo."
} 
From 1920 on, the process of identity construction mentioned above was implemented, in cultural terms, through a vast project of public education [educación popular]. This project was conceived and directed by José Vasconcelos (1882-1959), the head of the newly created Ministry of Public Education (Secretaría de Educación Pública [SEP]), and carried out in the different states of the Mexican Republic ${ }^{6}$ by the Directorate of Aesthetic Culture (Dirección de Cultura Estética). The project included construction of rural schools and programs of mass literacy, creation of workers' cultural centers, publication and distribution of domestic and European literary works, writing and dissemination of a new Mexican history, creation of institutions of higher learning (the National University), creation of libraries and museums, and promotion of arts under a nationalist aesthetics (particularly the visual arts and music). The directors of the SEP were conscious of the critical importance of the educational project in nation building, as one of its delegates expressed in 1922:

One of the purposes of the SEP is to strengthen the ties of nationality, because only then the Mexican homeland will be truly constituted. With this laudable aim, it is giving a great impulse to cultural aesthetics, which will make the beauty of our own soil be known and felt; which will cultivate the emerging Mexican music; which will make our poets and novelists sing our beauties; that architects cultivate indigenous styles in which they will find hitherto unknown beautiful motifs; that instead of being inspired by the masterworks of foreign artists, our painters will find inspiration upon the sublime and majestic creations of our exuberant nature; that the conceptions of art will have application in the industries, and finally, that the joys that music, painting, poetry, drama, provide will not be an exclusive privilege of a few, but heritage of all. ${ }^{7}$

The new appreciation of the pre-Hispanic past that had been repudiated for centuries and the desire for progress within modernity led to a general nationalist project. With regards to the arts, the nationalist discourses were varied, polymorphic, and occasionally, antagonistic. Since 1921, this movement of cultural construction had its strongest manifestations in the visual arts and literature, represented by the muralist and Stridentist movements, ${ }^{8}$ and in music, represented especially by Julian Carrillo (1875-1965), Manuel M. Ponce (1882-1948), and Chávez. Thanks to government intervention, both painters from the muralist movement and composers were given the task of creating a theory of a new Mexican identity and applying it to their works. Thus, with the support of José Vasconcelos, the muralists covered the old colonial buildings (the Ministry of Public Education and the National Preparatory School's Amphitheater, among others) with monumental frescos, and composers created various works with an indigenous-nationalist orientation, such as the opera Xulitl by Julián Carillo and the ballet El fuego nuevo by Chávez. As mentioned above, the new Mexican identity was constructed, on the one hand, by new appreciation of the pre-

\footnotetext{
${ }^{6}$ Mexico is a federal republic politically divided into thirty-one states and a federal district. Each of the states has a relatively autonomous administration from the central government.

7 "Escuela of Puebla: Speech read by the inspector general of education, José M. Bonilla, at the inauguration of the Centro Cultural Obrero and the Directorate of Aesthetic Culture in Puebla," in Boletín de la SEP 1, no. 2 (September 1992), 366, as quoted in Claude Fell, fosé Vasconcelos: los años del águila (1920-1925): educación, cultura e iberoamericanismo en el México postrevolucionario, Series historia moderna y contemporánea, vol. 21 (México: Universidad Nacional Autónoma de México, 1989), 74.

${ }^{8}$ The Stridentist movement (1921-27) was the only artistic avant-garde movement in Mexico. It sought to synthesize historical European and Latin American avant-garde movements, especially in the visual arts and literature. Given its iconoclastic, cosmopolitan character, the Stridentist movement did not meet of the nationalist requirements of the postrevolutionary regime, which completely withdrew its support, making the dissolution of this movement inevitable.
} 
Hispanic past and the European cultural inheritance and, on the other hand, by the assertion of a Mexican culture within the dominant Western culture, which was generally perceived as universal. This opposition was essential to forge [federar] and recognize the value of an imaginary Mexico with its own unique characteristics, which would occupy an important place in the modern Western world. The goal was to overcome with this new myth the past four centuries of colonialism. ${ }^{9}$

\section{Nationalistic Discourses and Music}

In the period between 1921 and 1952 the nationalist discourse in the arts played a pivotal role in the construction and legitimation of a hegemonic cultural identity on behalf of the post-revolutionary regime, which made this discourse official in the 1930s. It is impossible, however, to speak of coherence or aesthetic uniformity in all Mexican works considered to be nationalistic because of the variety of ideological positions in the discourses of Mexican artists. With respect to music, the positions and strategies with which composers sought to define and integrate a Mexican music within the dominant culture of the Western world were extremely heterogeneous and fluctuating. To mention a few: the recovery and arrangement of sophisticated harmonies from nineteenth-century popular music (Manuel M. Ponce), theoretical speculation based on a new microtonal subdivision of the octave (Julian Carrillo), the search for a harmonic and formal language capable of integrating popular music from the mestizo tradition (Silvestre Revueltas), or the recovery of native melodies to be integrated into large Western forms and the search for a primitive modernist aesthetics (Carlos Chávez). These ideological positions were decisive in the composers' struggle to attain control of institutional power. Not only artistic, but also political, factors came into play in this struggle, especially because of the enormous power given to government members for the support of the fragile independence of musical institutions.

Since the commission of El fuego nuevo in 1921, Chávez sought to secure a position in both the musical and institutional fields in the country, which were centered in Mexico City. Thus Chávez initiated a plan to justify his actions and his ideology within the field of music-made up of composers, institutions, influential groups, and audiences-through his writings and his musical activities in Mexico and the United States. Indeed, within the Mexican post-revolutionary context, the political dimension occupied a more prominent role for Chávez than it had had since the beginning of his artistic activities. He was a prolific writer of newspaper articles in which he expounded his ideas, sometimes in such a categorical manner that they would resemble small politico-artistic manifestos. Most of these articles are recognizably of a political character, reflecting his desire to justify his actions, legitimize his ideas, disseminate his educational thoughts, or respond publicly to attacks by other composers. The analysis of the evolution of his musical thought and the nationalistic discourse of his writings reveals both constant and variable ideological positions that allowed him to keep close ties to the post-revolutionary regime for over thirty years. Chávez's nationalistic ideas were neither immutable nor the product of ideological dogmatism, as often happens in a totalitarian regime, nor did they reflect the entire heterogeneous musical production [of his time] which included different styles and aesthetic orientations (native nationalism, modernism, neo-romanticism, and so on). Rather, he constantly adapted his ideas to the needs and political orientations of the current government, with which he had to negotiate. The authoritarian

\footnotetext{
${ }^{9}$ Mexico achieved independence from Spain in 1821, after 11 years of war. But because of the almost intact continuation of the political, social, and economical colonial structures, the century that separates the achievement of independence from the Mexican Revolution can be considered a continuation of the colonial regime.
} 
foundations of his aesthetic and sociological convictions, however, remained constant: understanding this aspect of his ideology is key to addressing the complex aesthetic, political, and ideological dimensions in the creation of Mexican music in the first half of the twentieth century.

Chávez was a staunch supporter of the state's action and control over art education and believed in the power of classical music to create a national consciousness, to which he also attributed a civilizing function [función civilizadora]. For these reasons, from the beginning of his career as a composer he had two aims: on the one hand, he attempted to establish the foundations of a national music and the originality of a Mexican school of composition; on the other hand, he sought to disseminate classical music among the masses in order to educate them aesthetically. This integration [of the masses] into a universal Western culture would then help the creation a national cultural unity. In 1916 Chávez wrote the article, "Importancia actual del florecimiento de la música nacional," in which he justified from a historical and evolutionary perspective the originality of the Mexican people, the mix of the Latin and Azteca blood:

Our lower class mestizos are artists because they have suffered for four centuries, and they feel the need of comfort and calm, thus creating [artworks], by necessity of their spirit. They express their deep pain and their brief moments of joy through their Latin sensibility and Indian stoicism in order to reveal what we Mexicans feel. And this is nothing more than the interpretation of the emotions of those who have in their veins Latin and Cuauhtémoc blood: it is thus the fruit of our blood and our soul, and it is beautiful and original. The latter is what constitutes the virtue that will be of great merit in the present times. "Why is it original?" It is because our people, precisely because of their lack of culture, have not been part of all phases of the evolution of thinking undergone by the human civilization-the civilization that drives the old Europe. That civilization characterizes in various ways all its feelings and situates its creative imagination in a different state; and because of that, its expression is also different from those of other peoples. ${ }^{10}$

These sentences contain two constant ideas in Chávez's nationalistic thought. The first, based on the notion of race, is the idea of the originality of the Mexico people, which is the result of its origins: preHispanic and European. The second, based on an evolutionary theory of cultures and in a teleological conception of history, is the idea of the permanence of Mexican culture and music, particularly the native melodies, in a stage of development prior to the one reached in Europe. These ideas gave Mexico the necessary elements for the emergence of nationalistic music and gave its protagonists the hope of occupying a significant place in the dominant Western culture. As we will see below, the belief in the social function of art music [música culta] as a creator of national identity complemented these ideas, making it the duty of the state to employ music to educate its people in order to achieve a unified national culture.

Between 1922 and 1924 Chávez traveled to Europe and the United States, where he had contact with contemporary music from those places. In New York he met Edgard Varèse and became a member of the International Composers' Guild, for which he became a correspondent and sponsor in Mexico. ${ }^{11}$ Subsequently, in late 1925 and early 1926, he organized the first concerts of contemporary music in Mexico, the New Music Concerts, which included works by Debussy, Satie, Schoenberg, Falla,

\footnotetext{
${ }^{10}$ Carlos Chávez, "Importancia actual del florecimiento de la música nacional," in Obras. 1: Escritos periodísticos (1916-1939), ed. Gloria Carmona (México: El Colegio Nacional, 1997), 7-10.

${ }^{11}$ Chávez included one of Varèse's works in contemporary music concerts in Mexico, and Varèse included Chávez's Otros tres hexágonos in a concert by the Guild on February 8, 1925. Chávez also wrote an op-ed article on music for the newspaper $E l$ Universal (published on January 4, 1925) in which he compares Varèse with Schoenberg and Debussy.
} 
Stravinsky, Bartók, Milhaud, Honegger, Poulenc, Auric, Varèse, and Revueltas. ${ }^{12}$ These concerts were only moderately successful in terms of their impact on the musical life of the city, but they were instrumental in forging the public image of Chávez within and outside the country. Indeed, from 1926 to 1928 Chávez moved back to New York and strengthened his ties, which had begun in his first trip two years before, with composers who belonged to the International Composers' Guild, particularly Copland, Cowell, and Varèse $^{13}$. Within the Guild, Chávez immediately occupied a unique place, representing a mixture of native exoticism and primitive modernism. For American composers and critics, Chávez represented one of the new paths for a Pan-American musical identity, as opposed to the European identity from which they also wanted to be differentiated and emancipated. The work of Chávez was perceived as modernist—just as Chávez himself had defined it—and eventually as primitive and savage, ${ }^{14}$ adjectives that Chávez accepted without opposition. Chávez's musical production in the period between 1921 and his return to Mexico in 1928 comprise only three works following the indigenista aesthetics-the ballets El fuego nuevo, Los cuatro soles, and Caballos de vapor (H.P.) —as opposed to the majority of his modernistic works, including Tres hexágonos, Otros tres hexágonos, Sonatina para piano, Sonatina para violín y piano, Sonatina para violoncello y piano, Energía, and Sonata num. 3 para piano. Despite the small number of works with a native aesthetics, Chávez forged an image of a profoundly Mexican modern composer, bearer of a characteristic mestizo identity of the American continent.

The acceptance of Chávez within the International Composers' Guild and his success in New York were fundamental in establishing his authority in the musical and institutional environments of Mexico. The Mexican regime perceived in Chávez a person capable of legitimizing its cultural policy with the United States and integrating Mexico into a Western cultural project. In fact, Chávez's aesthetic, social, and political ideologies did not contradict the hegemonic and nationalist concerns of the Mexican regime. Thus, upon his return to Mexico in 1928, Chávez was appointed director of both the National Conservatory and the Orquesta Sinfónica de México (OSM). These positions made him the most influential figure in the administration of music in Mexico. Thereafter, he held other strategic administrative positions. In addition to serving as the director of the National Conservatory and the OSM, he became the director of the Department of Fine Arts of SEP and later was the founder of the National Institute of Fine Arts (Instituto Nacional de Bellas Artes [INBA]), under which he organized musical education, and stimulated the national creation and dissemination of domestic and foreign contemporary music in Mexico.

\section{Music, Politics, and Aesthetic Education}

Despite the absence of a national state system to promote the production of domestic music, Chávez's activities were important for the dissemination and understanding of foreign contemporary music in Mexico. They were also a driving force for the promotion of domestic music. In the early 1930s, most Mexican composers wrote music regardless of the scarce commissions by the state. At that time,

\footnotetext{
${ }^{12}$ The soprano Lupe Medina and composer-violinist Silvestre Revueltas, among others, participated in these concerts. See Roberto García Morillo, Carlos Chávez: Vida y obra (México: Fondo de Cultura Económica, 1960), 39.

${ }^{13}$ The International Composers' Guild became the Pan American Association of Composers (PAAC) in February 1928 and Chávez was nominated as the regional director for Central America. See Deane L. Root, "The Pan American Association of Composers (1928-1934)," Anuario Interamericano de Investigación Musical, vol. 8 (1972), 49-70.

${ }^{14}$ On the construction of Chávez's image in the United States see Leonora Saavedra, "Carlos Chávez y la construcción de una alteridad estratégica," in Diálogo de resplandores: Carlos Chávez y Silvestre Revueltas, ed. Yael Bitrán and Ricardo Miranda, Series Teoría y práctica del arte (México, D.F.: Consejo Nacional para la Cultura y las Artes, 2002), 125-36.
} 
however, Chávez premiered a number of important domestic and foreign works with the OSM (see Figure 1) and reformed the academic programs of the National Conservatory.

In accordance with his institutional perspective, Chávez viewed the political orientation of official art as related to its intrinsic quality and the degree of its social influence. In 1930, he argued in his "Open Letter to the Youth" the paradoxical hypothesis that official art is sterile when its political orientation is to the right but fruitful when its political orientation is revolutionary:

The "official art," sterile by excellence, becomes fertile as soon as the official action is exercised by a revolutionary government. And then, the "left-wing" becomes official, with great regret of the right-wing, which engages in all sorts of useless and malicious intrigues. ${ }^{15}$

\begin{tabular}{|c|c|c|c|c|c|}
\hline \multicolumn{4}{|c|}{ OBRASMODERNAS } & \multicolumn{2}{|c|}{ MEXICANAS } \\
\hline $\begin{array}{l}\text { SKYSCRAPRES } \\
\text { MUSICA PARA TEATRO }\end{array}$ & $\begin{array}{l}\text { CARPENTER } \\
\text { COPLAND }\end{array}$ & GOPAK, PARA & & MARCHA TARASCA & CAS \\
\hline SINFONIA & COPLAND & $\begin{array}{l}\text { SOPRANO Y ORQ. } \\
\text { SINFONIA CLASICA }\end{array}$ & $\begin{array}{l}\text { MOUSSORGSKY } \\
\text { PROKOFIEFF }\end{array}$ & $\begin{array}{l}\text { EL FUEGO NUEVO } \\
\text { LOS CUATRO SOLES }\end{array}$ & $\begin{array}{l}\text { CHAVEZ } \\
\text { CHAVEZ }\end{array}$ \\
\hline ODA SINFONICA & COPLAND & CONCERTO PARA & & H. P. & CHAVEZ \\
\hline PEQUEÑA SINFONIA & COPLAND & VIOLIN Y ORQUESTA & PROKOFIEFF & ANTIG ONA & CHAVEZ \\
\hline SYNCHRONY & COWELL & SUITE DEL AMOR DE & & EL SOL & CHAVEZ \\
\hline $\begin{array}{l}\text { IBERIA } \\
\text { LA DONCELLA ELEGIDA }\end{array}$ & $\begin{array}{l}\text { DEBUSSY } \\
\text { DEBUSSY }\end{array}$ & $\begin{array}{l}\text { LAS TRES NARANJAS } \\
\text { TERCER CONCERTOPARA }\end{array}$ & PROKOFIEFF & $\begin{array}{l}\text { LLAM ADAS } \\
\text { EL YASO DE DIOS }\end{array}$ & $\begin{array}{l}\text { CHAVEZ } \\
\text { DOMINGUEZ }\end{array}$ \\
\hline NOCTURNOS: & & PIANO Y ORQUESTA & PROKOFIEFF & TRIPTICO SINFONICO & $\begin{array}{l}\text { DOMINGUEZ } \\
\text { ELIAS }\end{array}$ \\
\hline $\begin{array}{l}\text { NUBES, FIESTAS } \\
\text { NOCTURNOS: SIRENAS }\end{array}$ & $\begin{array}{l}\text { DEBUSSY } \\
\text { DEBUSSY }\end{array}$ & DAFNIS Y CLOE & RAVEL & SINFONIA EN DO MENOR & ELIAS \\
\hline LA SIESTA DEL FAUNO & DEBUSSY & $\begin{array}{l}\text { MA MERE L'OYE } \\
\text { LA VALSE }\end{array}$ & $\begin{array}{l}\text { RAVEL } \\
\text { RAVEL }\end{array}$ & $\begin{array}{l}\text { IMAGENES } \\
\text { SINFONIA }\end{array}$ & $\begin{array}{l}\text { HUIZAR } \\
\text { HUIZAR }\end{array}$ \\
\hline $\begin{array}{l}\text { EL MAR } \\
\text { EL HIJO PRODIGO: }\end{array}$ & DEBUSSY & BOLER० & RAVEL & SCHERZO SINFONICO & HUIZAR \\
\hline $\begin{array}{l}\text { EL HIJO PRODIGO: } \\
\text { RECITATIVO Y ARIA }\end{array}$ & & $\begin{array}{l}\text { SHEHEREZADE, PARA } \\
\text { SOPRANO Y ORQ. }\end{array}$ & RAVEL & $\begin{array}{l}\text { PUEBLERINAS } \\
\text { SINFONIA }\end{array}$ & $\begin{array}{l}\text { HUIZAR } \\
\text { MARISCAL. }\end{array}$ \\
\hline DE LYA & DEBUSSY & LOS PINOS DE ROMA & RESPIGHI & MINUETO & MALABEAR \\
\hline EL APRENDIZ DE BRUJO & DUKAS & SUITE DE LA & & DANZA TARAHUMARA & MENDOZA \\
\hline $\begin{array}{l}\text { EL AMOR BRUJO } \\
\text { NOCHES EN LOS }\end{array}$ & DE FALLA & REBAMBARAKRBA & ROLDAN & $\begin{array}{l}\text { HUAPANGO } \\
\text { PRELUDIO Y FUGA }\end{array}$ & POMAR \\
\hline NOCHES EN LOS & DE FALI A & CASTILLA & SAN JUAN & PRELLUDIO Y FUGA & \\
\hline $\begin{array}{l}\text { JARDINES DE ESPAÑA } \\
\text { TRES DANZAS }\end{array}$ & & $\begin{array}{l}\text { BABALUAYE } \\
\text { OCHO PIEZAS }\end{array}$ & SAN JUAN & $\begin{array}{l}\text { RITMICOS } \\
\text { TRES ROMANZAS, PARA }\end{array}$ & POMAR \\
\hline DEL SOM BRERO & & (ORQUESTACION DE & & CANTO Y ORQUESTA & PONCE \\
\hline $\begin{array}{l}\text { DE TRES PICOS } \\
\text { OBERTURA DE "LAS }\end{array}$ & DE FALLA & $\begin{array}{l}\text { HDEZ. MONCADA) } \\
\text { CANTO DE LOS }\end{array}$ & SATIE & $\begin{array}{l}\text { CHAPULTEPEC } \\
\text { CHAPULTEPEC }\end{array}$ & PONCE \\
\hline NOTICIAS DEL DIA" & HINDEMITH & BOTEROS DEL VOLGA & STRAWINSKY & (NUEVA VERSION) & PONCE \\
\hline PACUFIC 231 & HONEGGER & SUITE DEL & & ESQUINAS & REVUELTAS \\
\hline RUGBY & HONEGGER & PAJARO DE FUEGO & STRAWINSKY & VENTANAS & REVUELTAS \\
\hline CONCERTINO PARA & & FUEGOS ARTIFICIALES & STRA WINSKY & CUANAHUAC & REVUELTAS \\
\hline PIANO Y ORQUESTA & HONEGGER & PETROUCHKA & STRAWINSKY & JANITZIO & REVUELTAS \\
\hline ESCALAS & IBERT & SINFONIA DE SALMOS & STRAWINSKY & CAMINOS & REVUELTAS \\
\hline $\begin{array}{l}\text { CATALOGO DE FLORES, } \\
\text { PARA SOPRANO }\end{array}$ & & $\begin{array}{l}\text { LAS BODAS } \\
\text { SUITE NO. } 2 \text { PARA }\end{array}$ & STRAWINSKY & $\begin{array}{l}\text { PLANOS } \\
\text { SCHERZO SINFONICO }\end{array}$ & $\begin{array}{l}\text { REVUELTAS } \\
\text { ROLON }\end{array}$ \\
\hline Y ORQUESTA & MILHAUD & PEQUEÑA ORQUESTA & STRAWINSKY & CUAUHTEMOC & ROLON \\
\hline EL BUEY SOBRE EL TEJADO, & & CONCERTO PARA & & BAILE MICHOACANO & ROLON \\
\hline $\begin{array}{l}\text { PARA VIOLIN Y } \\
\text { ORQUESTA }\end{array}$ & & PIANO Y ORQUESTA & STRAWINSKY & $\begin{array}{l}1895 \\
\text { PARAFRASIS DE }\end{array}$ & ROLON \\
\hline $\begin{array}{l}\text { ORQUESTA } \\
\text { FUNDICION DE ACERO }\end{array}$ & $\begin{array}{l}\text { MILHAUD } \\
\text { MOSSOLOFF }\end{array}$ & $\begin{array}{l}\text { CONCERTO PARA } \\
\text { PIANO Y ORQUESTA }\end{array}$ & TCHEREPNINE & $\begin{array}{l}\text { PARAFRASIS DE } \\
\text { "SOBRE LAS OLAS" }\end{array}$ & MARRON \\
\hline $\begin{array}{l}\text { TREPAK, } \\
\text { PARA SOPRANO Y ORQU }\end{array}$ & $\begin{array}{l}\text { MOUSSORGSKY } \\
\text { ESTA }\end{array}$ & INTEGRALES & YARESE & $\begin{array}{l}\text { PATRIA HEROICA } \\
\text { SONATA TRAGICA }\end{array}$ & $\begin{array}{l}\text { TELLO } \\
\text { TELLO }\end{array}$ \\
\hline & & & & POEMA SINF ONICO & VAZQUEZ. \\
\hline & & & & $\begin{array}{l}\text { YALS POETICO } \\
\text { CAUSERIE, YALS }\end{array}$ & $\begin{array}{l}\text { VILLANUEVA } \\
\text { VILLANUEVA }\end{array}$ \\
\hline
\end{tabular}

Figure 1. Mexican and foreign works performed by the Orquesta Sinfónica de México in 1928-34. Detail of the 1935 season.

\footnotetext{
${ }^{15}$ Chávez, "Carta abierta a la juventud," Música: Revista mexicana 1, no. 1 (1930), 3-5, as quoted in Olga Picún, "Jacobo Kostakowsky en México: Una aproximación al contexto musical de los años treinta," Anales del Instituto de Investigaciones Estéticas 28, no. 88 (2006), 169-202.
} 
However, Chavez's political convictions were fluctuating and contradictory, as shown by his ideological adaptation to the various governments of the Mexican regime and by his aesthetic positions toward art music and Mexican folk music. In fact, contrary to the Marxist positions of several of his contemporaries, ${ }^{16}$ Chávez did not believe in the use of music as a vehicle to resolve class struggle and achieve a more just society. Chávez favored hierarchies between folk and art music, which were related to his evolutionary conception of culture. "Music is always conditioned by the degree of intellectual development of the society that produces it," he declared in 1934. ${ }^{17}$ These hierarchies had a dual function: first, they legitimized his activities as composer and administrator of the construction of a Mexican culture that he considered to be of high level; and second, they served to establish a nationalist discourse through aesthetic education of the masses, thus integrating Mexico into a universal Western culture. His sociological ideas about the role of music were grounded in a belief in the intellectual superiority and significance of Western art music as a universal language. He expressed this view in 1929, when he launched and explained the new social and educational activities of the National Conservatory of Music:

Do not think that the socializing task of art consists in adopting the artwork from the unprepared or uneducated masses. On the contrary, the work of socialization should be to impose the beauty of high art [arte superior] on people who ignore it or hardly understand it. It is in this way that art, and especially music, is distinguished from other human activities: it is impossible, for example, to impose upon uneducated and primitive masses the tenets of scientific reasoning, but the highest forms of musical art speak with eloquence and depth to any person or any crowd, no matter how uneducated or unprepared they are. ${ }^{18}$

As mentioned earlier, Chávez attributed to music the power to educate the masses aesthetically and to profoundly shape the character of individual citizens. This conception of the social role of music was in agreement with the hegemonic concerns of the authoritarian Mexican regime, justifying his intervention and control of the musical scene through artistic institutions. In 1934 Chávez supported the postrevolutionary regime's interest in using art as a symbolic vehicle to educate the population aesthetically:

The governments that succeeded the Porfirian regime have recognized the importance of the education of the working masses through art and have implemented important lines of their expenditure budgets for this purpose. ... Art is a human phenomenon, which the state must promote and use as a weapon to educate the proletarian class. ${ }^{19}$

As for the particular position of music in such aesthetic education of the masses, Chávez gave it a central place because of its uniqueness in being a "less specific" language than verbal language:

It is important to note the crucial role that music plays as one of the factors in the education of the masses: music, as an agent of expression of feelings and thoughts, reaches a level of intensity even higher than spoken language; if words accurately establish concepts and make reasoning possible, music, as a less specific language, directly influences the formation of habits,

\footnotetext{
${ }^{16}$ Particularly Silvestre Revueltas (1899-1940), José Pomar (1880-1961), and Jacobo Kostakowsky (1893-1953). These three musicians were politically active in the ranks of the League of Revolutionary Writers and Artists (LEAR, 1934-38), an antifascist organization of communist-, anarco-unionist-oriented intellectuals.

${ }^{17}$ Chávez, "El arte en la sociedad," in Obras. 1, 247-51.

${ }^{18}$ Chávez, "Una nueva actividad del Conservatorio Nacional," in Obras. 1, 141-43.

${ }^{19}$ Chávez, "Arte proletario," in Obras. 1, 259-63.
} 
the formation of taste, in the formation of feelings. In short, the formation of the individual character. $^{20}$

Thus informed by the social and political role of art music as a creator of a cultural unity through aesthetic education, the state had the responsibility and obligation to promote and control it. The control of production and dissemination of art is a constant concern within totalitarian and authoritarian regimes of the twentieth century, which tend to see arts as important symbolic catalysts that require their direct control. State agencies censor the content of art to ensure that it does not contradict the official ideology. In the case of the Mexican authoritarian regime, control over artistic dissemination was exercised through the major musical institutions: the National Conservatory of Music, the OSM, and the Department of Fine Arts of SEP, all under the direction of Chávez at a given moment. ${ }^{21}$ The unique feature of this institutional policy was the promotion and free circulation of foreign contemporary music next to domestic productions. Chávez's place as a member of the International Composers' Guild was decisive for the dissemination and promotion of contemporary music in Mexico and for the visibility of certain Mexican music in the United States. Symbolically, the presence of foreign music allowed, by contrast, the affirmation of characteristically national music. However, aesthetic control over the production of music was not systematized: it was exercised through a power struggle among different groups of active composers. As I shall explain later, official control over music production was not established until the end of 1946 with the creation of the National Institute of Fine Arts (Instituto National de Bellas Artes [INBA]), a project presided over and directed by Chávez.

\section{Nationalism and Social Reconciliation}

The Orquesta Sinfónica de México was responsible for the presentation of classical and contemporary music in Mexico in its regular seasons as well as within the context of official events of considerable significance. In 1934 the OSM and the National Conservatory Choir participated in the inauguration of the Palace of Fine Arts, ${ }^{22}$ performing the National Anthem, Chávez's Llamadas: Sinfonía proletaria (for mixed choir and orchestra), and Beethoven's Sixth Symphony. Given the importance the authoritarian regime gave to the Palace of Fine Arts as a new center of national culture where all social classes would meet as a step toward a national reconciliation, this act had a great symbolic significance. The Sinfonía proletaria of Chávez is an exception in his output because its aesthetic is close to that of social realism. The work is based on the text of Corrido de la Revolución from Diego Rivera's murals, which constitutes an apology for the virtues of the proletarian class as opposed to a decadent and sterile bourgeois culture. The score, in piano reduction, was published by the Department of Fine Arts of SEP in the same year, but Chávez no longer directed this work on any other occasion. ${ }^{23}$ This work, like the Obertura Republicana, which I shall address below, seems to obey the new socialist, conciliatory ideology promoted during President Lázaro Cárdenas’s term. Indeed, Cárdenas’s government was sustained by populist

\footnotetext{
${ }^{20}$ Chávez, "Los conciertos para trabajadores," in Obras. 1, 265-67.

${ }^{21}$ Chávez was appointed director of the National Conservatory from 1928 to 1934 (a period interrupted only for him to serve as the Head of the Department of Fine Arts of the SEP in 1933-1934), and the director of the Orquesta Sinfónica de México from 1928 to 1948. From 1946 to 1952 he was appointed director of the newly created National Institute of Fine Arts (INBA).

22 The Palace of Fine Arts was the new national theater destined to be the main center for dissemination of the arts. It was also used by President Lázaro Cárdenas and his successors for many political activities.

${ }^{23}$ On Chávez's Llamadas: Sinfonía proletaria, see Julio Estrada, “Carlos Chávez: -¿Quiénes son los otros?,” Perspectiva Interdisciplinaria de Música, no. 3-4 (2009-2010), 7-32.
} 
politics, as it promised economic development based on social justice. It also organized confederations of workers and peasants unions, continued land reform, expropriated the oil and mining industries from foreign companies, and instituted socialist education in Mexico, among other things. The presence in the program of Beethoven's Sixth Symphony confirms the will of the Mexican regime to integrate Mexico into the dominant Western culture, which was perceived as universal. So, on the one hand, it confirmed the institutionalization of the ideals of the revolution under a socialist optics and, on the other hand, it affirmed the insertion of Mexico in a universal Western culture. Both the Sinfonía proletaria and Chávez himself were severely criticized by Mexican intellectuals of anarchist or communist convictions, as was the case with the League of Revolutionary Writers and Artists (Liga de Escritores y Artistas Revolucionarios [LEAR] $),{ }^{24}$ who saw Chávez as the regime's new official composer. The rationale behind these criticisms was confirmed on December 1, 1934, when the Orquesta Sinfónica de Mexico accompanied the inauguration of President Cárdenas with works by Beethoven, Chávez, and Revueltas under the direction of Chávez in the same Palace of Fine Arts.

A year later, Chávez affirmed in his article entitled "Concerts for workers" the importance of the role of the OSM in the "cultural growth of the working classes and workers," defining it as "a cultural institution whose key mission is to spread music to all the inhabitants of the country, thus contributing to the education of its people." 25 Indeed, in 1935 the OSM offered a series of concerts aimed at a proletarian audience in which Chávez premiered his Obertura Republicana, a piece based on three popular Mexican melodies of the nineteenth and early twentieth centuries: the Marcha de Zacatecas, the waltz Club Verde, and La Adelita. Chávez defined these pieces as "genuinely Mexican, popular and mestizo, encompassing a large amount [dosis enorme] of Republican expression."26 The piece is developed tonally, exposing and developing themes in succession through imitative and contrapuntal techniques within a festive and caricatural environment. For Chávez, to integrate popular Mexican music with symphonic forms was to do justice to the Mexican race as the bearer of historical truth, as he argued in the article cited above:

For a century, the mixed race of Mexico was nourished with simple, small-town music. . . No one can doubt, upon hearing these delicious harmonies characteristic of our Mexico, that this music belongs to a time and a place: here is the "national" music, but of nineteenth-century Mexican nationality. We can do nothing better than collect it in its purity and in its real authenticity and offer it among the truths that music of all times and all countries is capable of saying to present and future generations. ${ }^{27}$

Chávez's search for a national musical identity in those years was marked by an ideal integration of the different musical cultures of the social classes that comprised the Mexican nation. His own ideological position, which opposed the "beauty of high art" to art "from unprepared or uneducated crowds," 28 shifted to a more moderated, conciliatory position. This aesthetic-political shift was closely related to the new politics of the government of Cárdenas (the same way in which his positions changed with the ideologies of the future governments of the Regime) and to Chávez's desire to integrate the social classes, including the Mexican indigenous peoples. Thus, the evolution of his national ideals included both contemporary

\footnotetext{
${ }^{24}$ See LEAR's official publication Frente a Frente, no. 1 (1934; reprint, México, Centro de Estudios del movimiento Obrero y Socialista, 1994).

${ }^{25}$ Chávez, "Los conciertos para trabajadores," 265-67.

${ }^{26}$ Chávez, "Obertura Republicana," in Obras. 1, 269-70.

${ }^{27}$ Ibid., 270.

${ }^{28}$ Chávez, "Una nueva actividad del Conservatorio Nacional," 141-43.
} 
native music and popular music. For Chávez, the large Western symphonic forms were a vehicle with which to firmly establish [consagrar] this Mexican music and convert it into a high art form. This way, Chávez accomplished the social mission of a popular reconciliation and the creation of a high-level national culture. This conception was reflected in his most famous work, which established him as a composer in Mexico and the United States: his Sinfonía India.

In late 1935 the American broadcast company CBS commissioned a symphony from Chávez to be premiered and broadcasted via radio in the following year. So, on January 23, 1936, Chavez's Sinfonía India was premiered in New York alongside two other works of indigenous influence composed by Mexican composers: U Kayil Chaac by Daniel Ayala and El venado by Luis Sandi. In his work, Chávez uses native melodies (Coras, Seris, and Yaquis) as thematic materials; these melodies were collected between 1906 and 1907 by the German ethnologist Konrad T. Preuss (1869-1938) and published in Leipzig in 1912. ${ }^{29}$ Chávez considered these native melodies to be authentic, and presented them as such in the program and integrated them within a tonal symphonic context in an orchestra that included pre-Hispanic, native percussion instruments. The success of this work in the United States and its repercussion in Mexico was immediate, despite the errors in the discourses on the origin and characteristics of these melodies. Indeed, as the German musicologist Erich M. von Hornbostel (1877-1935), who transcribed these melodies into Western notation for Preuss's publication, had already observed, the melodies had a strong European influence. ${ }^{30}$ This fact also explains the ease with which Chávez integrated them without any modification into a tonal language within a symphonic form. ${ }^{31}$ Nevertheless, American critics were enthusiastic of Chávez's Sinfonía India, largely because of the ostensible synthesis between authentic indigenous materials and Western forms. In Mexico, the work became the official paradigm for a Mexican school of composition. Charles Seeger stated in his review of the score in 1950, "no doubt Sinfoní India is one of the best works of Chávez, and one of the most sublime recently produced in the hemisphere"; and in 1960 the critic Richard Frank Goldman stated in his record review,

Sinfonía India represents perhaps the best kind of sophisticated primitivism in modern music, and it can still be a lesson to all the other composers who have tried this. Given that it has, to begin with, native material of considerable interest, Chávez works out the theme with a strong and vigorous imagination. ${ }^{32}$

In 1936 Chávez started intense activity as guest conductor in numerous orchestras and as a composer in the United States, receiving invitations and commissions from various personalities, institutions, and foundations (Guggenheim Foundation, Coolidge Foundation, Harvard University, UNESCO). The establishment of Chávez in America through his role as an exotic composer and bearer of a sophisticated primitivism solidified his position within the official musical culture in Mexico.

\footnotetext{
${ }^{29}$ For an analysis of these melodies and its reception Sinfonía India, see Robert Stevenson, "El sistema melódico de los aborígenes primitivos [de México: los coras y los huicholes] y la Sinfonía India de Carlos Chávez," in Fiesta, literatura y magia en el Nayarit. Ensayos sobre coras, huicholes y mexicaneros de Konrad Theodor Preuss, ed. Jesús Jauregui and Johannes Neurath (México: Instituto Nacional Indigenista-Centro Francés de estudios mexicanos y centroamericanos, 1998), 187-99.

${ }^{30}$ See Erich von Hornbostel, “Anhang: zwei Gesänge der Cora-Indianer [...] (Aus dem Phonogramm-Archiv des Psychologischen Instituts der Universität Berlin). I. Melodien und Formalanalysen,” in Konrad Theodor Preuss, Die NayaritExpedition (Leipzig: B. G. Teubner, 1912), 366-76. Published in Spanish as "Melodías y análisis formales de dos cantos de los indios coras," in Fiesta, literatura y magia en el Nayarit, 29-40.

${ }^{31}$ For a comparative analysis of Sinfonía India, see Luis Velasco Pufleau, “Musique et identité: l'œuvre de Carlos Chávez et Silvestre Revueltas," in Musique et construction des identités nationales au XIXe siècle, Series Collection d'études musicologiques, ed. Beat A. Föllmi, Nils Grosch, and Mathieu Schneider (Baden-Baden: Valentin Koerner, 2010), 113-36.

${ }^{32}$ Quoted in Stevenson, "El sistema melódico de los aborígenes primitivos," 198.
} 
In his 1936 article "Nacionalismo y futurismo" (Nationalism and Futurism), Chávez exposed his new conception of a nationalist music, which corresponded to the aesthetics and reception of his Sinfonía India:

To delimit with precision the extent and boundaries of a nationality and, at the same time, the extension and boundaries of national culture and music [within that nationality] is an impossible task: a nation, to actually be one, must be a unified core of individuals related by the community of race, language, and customs. We already know that states do not generally correspond to nationalities; i.e., a state, a political entity, contains a variety of nationalities (Mexico is as such a typical case). ... Convinced that nationality is a feature always in evolution, I find it sensible to call Mexican the music from the Huichols, Yaquis, or Seris Indians as well as a billion [mil millones] cases of other racially mixed music: sones, songs, corridos, huapangos, jarabes, sandungas, symphonies, operas, etc. Because of this, I cannot accept that it is possible to declare none of those cases to be the archetype of Mexican music. ${ }^{33}$

In this text, Chávez seems to defend an extremely tolerant and conciliatory cultural and political vision, one that was based on the coexistence of people (nationality) and state, and the inclusion of all musical cultures of Mexico without emphasis on any in particular. His Sinfonía India reveals, however, that for him the aesthetic institutional models of the Western musical tradition were superior to the mestizo or native models of Mexico. The integration of autochthonous materials and musical practices within the model above would ensure the introduction and recognition of Mexico within Western modernity. This politicoaesthetical strategy was confirmed in 1940, when he was commissioned to present a series of concerts of Mexican music in the exposition "Twenty Centuries of Mexican Art," organized by the Museum of Modern Art (MOMA) in New York. Chávez presented a program that included, for the most part, his own works: the arrangement for chorus and orchestra of the popular song La Paloma Azul, the orchestral works Xochipilli-Macuilxochitl and Obertura Republicana (the latter performed under the titles Marcha, Vals, and Canción), and fragments of his ballet Los cuatro soles. The remainder of the program presented works of similar styles, including arrangements of mestizo or native music of Blas Galindo, Candelario Huizar, Jerónimo Baqueiro Fóster, Vicente T. Mendoza, and Luis Sandi. The program, emphasizing primitivism and exoticism, was meant to represent the variety of musical cultures in Mexico ${ }^{34}$ and its historical evolution: from an imagined pre-Hispanic music orchestrated for pre-Cortesian instruments (XochipilliMacuilxochitl) to mestizo music arranged for chamber orchestra (corridos, sones, and huapangos).

Chávez's nationalist ideal turned out to be hegemonic, especially because of his desire to integrate Mexican musical cultures within the modern Western world through to his efforts in combining Mexican music with musical forms of the Western tradition and his presentations in concert venues. His significant vision of music as a profound expression of the essence of human beings, coupled with his teleological and historicist views on the development of culture, led him to equate musical evolution with the evolution of the Mexican nation, as he expressed in his 1941 essay:

Music is the quintessential expression of humans, the clearest symptom (alongside other arts) of the human capacity of sublimating emotions. Music is a direct expression of individuals, but because individuals do not live on an island, but within the nation to which they belong, their

\footnotetext{
${ }^{33}$ Chávez, "Nacionalismo y futurism," in Obras. 1, 279-85.

${ }^{34}$ See Herbert Weinstock and Carlos Chávez, Mexican Music (New York: Museum of Modern Art, 1940).
} 
music is by force [porfuerza] nationalistic. This music sums up the national antecedents inherited from thousands of previous generations as well as the influences from the social environment within which they were produced. .. Thus Mexican music exists in shape and form as much as a Mexican nationality exists. In other words: Mexican music registers a constant and complex process of integration parallel to the Mexican nation. ${ }^{35}$

Politically, Chávez gradually moves away from socialist ideas (such as the notion of art carrying an infallible sense of class), which he had adopted temporarily during the administration of President Cárdenas, to develop a conception of art as a manifestation of a national essence forged and transmitted over generations. This ideological change was parallel to the nationalist and anti-communist shift in the political orientation of the government under the presidency of Manuel Ávila Camacho (1940-46). In fact, one of the consequences World War II was the rapprochement and cooperation between Mexico and the United States Among the immediate consequences was the negotiation and reconciliation between the different political groups within a new capitalist, anti-fascist, and anti-communist doctrine. An example of the anti-communist stance of the government of Ávila Camacho was the reform of Article 3 of the Political Constitution of the United Mexican States in December 1945, which repealed the socialist education instituted in 1934 by Lázaro Cárdenas. Among the objectives of this reform was "the harmonious development of the intellectual capabilities [facultades] of human beings, the nurturing of love for the homeland, and the consciousness of international solidarity in independence and justice." 36 The control of the workers and peasant unions, alongside an internal reform of the Party of the Revolution, resulted in political stability supported by institutions that allowed the future government of President Miguel Alemán (1946-52) to establish presidential authoritarianism. ${ }^{37}$

During the presidency of Ávila Camacho, Chávez established himself as the most important musical figure in Mexican politics, both within and without the Mexican borders. On July 19, 1945, while still a candidate to the presidency of Mexico, Miguel Alemán offered Chávez an homage for his eighteen-year tenure at the Orquesta Sinfónica de México in the Club France. A few months later, in the final report of the government of Ávila Camacho, Chávez appears as the paradigmatic figure in the nation building efforts because of his creation of an individual art with a universal character:

Philosophy is no longer the work of lonely [individuals], of the extravagant. The philosopher is no longer a misunderstood genius, being transformed into an active member of the culture of his country . . . affirms [Leopoldo] Zea. Likewise there are in music streams of signs similar to the Aboriginal sensibility (as in Chavez's Sinfonía India) and themes of popular music enrich strictly Western expressions ... The human background we have noted in our lyrics reappears

\footnotetext{
${ }^{35}$ Chávez, 'La Revolución mexicana y la música," in Obras. 2: Escritos periodísticos (1940-1949), ed. Gloria Carmona (México: El Colegio Nacional, 2000), 31-33.

${ }^{36}$ Luis Medina, Del cardenismo al avilacamachismo, Historia de la Revolución Méxicana, vol. 18 (México: El Colegio de México, 1978); quoted in Gloria Delgado De Cantú, Historia de México II: De la era revolucionaria al sexenio del cambio (México: Pearson Prentice Hall, 2007), 262.

${ }^{37}$ For an analysis of the evolution of the Mexican authoritarian regime during the administration of President Miguel Alemán, see Luis Medina, Civilismo y modernización del autoritarismo, Historia de la Revolución Méxicana, vol. 20 (México: E1 Colegio de México, 1979).
} 
in music. Music obtains, without forgetting the universal spirit, the universal expression of our soul ... ${ }^{38}$

\section{Authoritarianism and the Creation of Nationalism: The National Institute of Fine Arts}

On September 30, 1945, Miguel Alemán published in the major newspapers of Mexico the "Síntesis del Programa de Gobierno del Lic. Miguel Alemán [Sythesis of Miguel Alemán's Program of Government]" in which he exposed his initiative to establish the Institute of Fine Arts, in case he would be elected president in the following year. He stated:

In order to stimulate those who are endowed with creative artistic genius, the Institute of Fine Arts will be created as a separate agency, but subject to the orientation given by the state. Those who have excelled in the arts, auditory or visual, will attend. ${ }^{39}$

In early 1946, still as a candidate, Alemán placed Chávez as the head of the Cultural Committee of Alemán's National Campaign (Comisión Cultural del Comité Nacional Alemanista) to elaborate a "Plan for the Fine Arts," which would be later converted into the official project for the National Institute of Fine Arts (Instituto Nacional de Bellas Artes [INBA]). As Chávez explains it, "the foundation of the Institute constituted a reorganization of funds from the branch of fine arts that had traditionally functioned as part of the Secretariat of Public Education under various names (until the end of 1946, General Directorate of Extra-Curricular and Aesthetic Education and, formerly, Department of Fine Arts)." ${ }^{40}$ On July 1 of the same year, the Cultural Committee delivered the Plan for the Fine Arts (the future Fine Arts Act) which affirmed, "if the creation of art matters to Mexico, it is the creation of a Mexican art that matters, a national creation," clarifying at once the nationalist orientation established by the state. In effect, the Fine Arts Act defined art as the "most sincere expression of the national spirit" and announced the kind of art to be promoted by the state:

The preambles [considerandos] of the Fine Arts Act clearly set forth the general principles by which it was inspired. The significance of some of these principles, and the necessary brevity by which it has to be exposed in such document, makes it advisable to further discuss them even if only briefly. This is the case of the first preamble, which states: "Whereas the artistic expressions of all orders are the most sincere and vigorous expression of the national spirit ..."

This simple declaration contains a group of important ideas.

I. The most sincere and vigorous expression of the national spirit is produced through art;

II. Art is a phenomenon to which we must attribute an expression of national character;

III. For the state, art that expresses the national spirit matters the most. ${ }^{41}$

\footnotetext{
${ }^{38}$ Jorge González Durán, "La superación cultural," in Seis años de actividad nacional (México: Secretaría de Gobernación, 1946), 161; quoted in Ricardo Pérez Montfort, “Carlos Chávez en los años cuarenta: caudillo o cacique cultural,” in Bitrán and Miranda, Diálogo de resplandores, 182-92.

${ }^{39}$ Chávez, "Una iniciativa del Licenciado Alemán," in Obras. 2, 539-41.

${ }^{40}$ Chávez, "Bellas Artes," in Obras. 2, 481-93.

${ }^{41}$ Ibid., 491.
} 
The Fine Arts Act placed arts in a position to strengthen the national character and integrate its ostensible universal dimension, to which Mexico would provide the genius of her artists. Indeed, within the international postwar context, the legitimacy of the democratic Mexican regime was central to President Miguel Alemán, who attached great importance to the symbolic and political roles of art, as evident in the ideological foundations of the Fine Arts Act:

The stimulus to the development of arts in Mexico signifies:

1. The strengthening of character and national personality, which automatically brings a general movement of national allegiance.

2. The aggrandizement of the universal cultural heritage through contributions made by the talent and the genius of Mexicans, highlighting the position of our country within a universal culture.

3. The development of the artistic activities with universal appeal in Mexico, which would be attractive to international audiences.

All these factors are, of course, of great educational and cultural significance. But they also have a very important presence in politics and economics. ${ }^{42}$

The INBA was created by a presidential decree on December 31, 1946. With Chávez as its director, it was converted into an institution by which the authoritarian Mexican regime would exercise full control over the production and dissemination of art produced in Mexico. For Chávez, the "Plan for the Fine Arts of president Alemán established the principles for a Fair Political Theory [teoría política justa] in the subject of fine arts" and that "the State must pay attention, for its evident importance, the role that arts, in all its manifestations, is capable of exercising in the consolidation of a Mexican identity [mexicanidad]." ${ }^{43}$ The evolution of the notion of a Mexican national identity, the so-called mexicanidad, during the presidency of Alemán, led Chávez to free himself from his own ideological notion of a cultural diversity, as well as the notion of a social content present in music and the arts. The politics of the authoritarian Mexican regime, exacerbated by the anti-communist statement of President Truman (published in the Mexican press on March 13, 1947), proposed a development of Mexican culture and art according to the duality nationalism/anti-communism and the establishment of a Mexican identity of an evolutionary character that would historically integrate the diversity of the country.

Chávez radicalized his nationalist ideology, considering the higher forms of art to be the direct manifestation of the national spirit and granting the state the duty of censoring and promoting these forms of art. This is expressed in his 1946 periodical article "Arte y Estado [Art and State]," in which Chávez includes an ethical dimension that had been absent in his writings up to that point:

Any act, thing, or person possesses in principle a quality. The good is positive. The bad is negative. Well. Everything that is not good is necessarily bad. Life that is not good and beautiful is necessarily miserable and sad. ... If the purpose of the state is to promote the good and beautiful life of individuals, not to fulfill it entirely is not to fulfill it at all. ... If a state organization, whatever it might be, does not promote and sustain the culture of higher forms of art, there will inevitably arise spurious manifestations, or pseudo-art. Pseudo-art is a serious social evil that corrodes and corrupts the independence [sustantividad] of social institutions....

\footnotetext{
42 Ibid., 483.

${ }^{43}$ Chávez, "El Museo de Bellas Artes," in Obras. 2, 495-504.
} 
Art, as a higher form of culture-music, dance, arts, theater, literature-is the most effective means of creating social health, linking individuals in the community, elevating ethical standards, and strengthening the national character. ${ }^{44}$

The ethical and moral dimensions that Chávez includes in his discourse on art justify the state's intervention as censor to prevent an alleged corruption of society by a pseudo-art, which it fails to define. Indeed, art ceases to be simply "conditioned by the degree of the intellectual development of the society that produces it" ${ }^{\$ 5}$ (the criteria used to establish qualitative hierarchies) to potentially become an evil that corrodes the "independence [sustantividad] of the same society," therefore giving the State the duty to intervene to promote an art that corresponds to the ideal of a "good and beautiful" life. The inclusion of this dimension implies a metamorphosis in Chávez's nationalist ideology into a totalitarian vision of artistic production. Chávez could not, however, develop or concretely implement this vision because of the absence of state structures of pressure and control in Mexico, structures characteristic of totalitarian regimes.

The authoritarian Mexican regime, represented perfectly by President Alemán, granted Chávez, as the Director of INBA, official power over the arts. This power surpassed the kinds that Chávez had amassed in the past. The critical reactions by artists against Chávez were numerous and bitter, especially because of his use of power for his own benefit, but also because of his dictatorial methods in implementing those powers. The monopoly Chávez exerted in the dissemination of his work, as opposed to other Mexican composers or composers living in Mexico, is evident in the programs of the OSM in the seasons between 1945 and 1948. Chávez programmed works by other Mexican composers or composers living in Mexico only in thirty-seven out of the sixty-one concerts that constituted the final four concert seasons of the OSM, after which the orchestra was terminated. He conducted thirty of these concerts, which included twenty of his own works, the equivalent of more than half of the Mexican works performed. ${ }^{46}$ Facing the critical responses about the high number of performances of his pieces on the OSM programs, Chávez provided the following response in March 1948:

It is natural to do so. Though, even more of my works should have been performed, so long as, in the first place, the audiences receive them very well and, in the second place, because I am the artistic director in charge of the programs, it is music that most draws my personal interest. ... So natural ... it is that I use the opportunity that the Sinfónica [de México] gives me to perform my own music. ${ }^{47}$

In 1947 Chávez used his official power to establish the National Symphony Orchestra (Orquesta Sinfónica National [OSN]), a new official orchestra under the INBA, which was created by a presidential decree on July 10 of the same year. Such an action had no precedents in the history of Mexico. Already in 1945, Chávez had attempted to resign his position as the Director of the OSM, citing as a reason his desire to dedicate himself completely to composition. He resigned effectively from that position in 1947. Initially, however, Chávez contemplated keeping the OSM in existence for his personal, private use:

\footnotetext{
${ }^{44}$ Chávez, "Arte y Estado," in Obras. 2, 267-69.

${ }^{45}$ Chávez, "Una nueva actividad del Conservatorio Nacional."

${ }^{46}$ See Picún, "Jacobo Kostakowsky en México," 169-202.

${ }^{47}$ Chávez, "Carta a Antonio Rodríguez," in Obras. 2, 393-400.
} 
The Sinfónica de México will play works of a more limited character and, inevitably, works of a more personal character, i.e., it will be openly an orchestra that we make it to be-Council and Director-and the concerts of the Sinfónica de México will be the Carlos Chávez Concerts as were, for example, the "Koussevitsky Concerts" in Paris, or the "Straram Concerts." 48

Under widespread criticism, however, Chávez gave up his project of converting the OSM into his personal orchestra and the board of directors of the OSM, in addition to accepting Chávez's resignation, dissolved the association that supported the orchestra. Thereafter, the Orquesta Sinfónica Nacional absorbed all personnel of the OSM and placed it under the authority of the INBA, allowing Chávez to maintain direct official control over its director, staff, programs, and activities.

The discontent on the part of musicians was prominent, with persistent public attacks against Chávez. On June 14, 1948, the conductor José Yves Limantour published a letter that harshly denounced the artistic dictatorship of Chávez and urged the opening of the official artistic field to composers and directors in Mexico:

Maestro Chávez does not allow the realization of cultural crusades that are not under his control and do not give him some personal benefit, not specifically in the infrastructure, but in the control. And it may well be the case that his egocentrism stopped movements that could have resulted in positive benefits to the nation, thus creating a perennial obstacle to innovations, which allowed him to exploit his official position for his own benefit. At this pace, soon we will be in an artistic dictatorship, if we are not already in one; and if dictatorship is odious in the political arena, it is much more so in the artistic and cultural fields: with a dictator there can be order and even peace, but never progress. It is better then to have a chaotic state in which to enjoy, at last, the freedom to think. . . If we do not take advantage of this moment, which has not yet reached the climax of desperation toward the totalitarian system in the arts, soon the boiler whose valves were closed for a long time will explode and, then, the prestige that Maestro Chávez has ever achieved on the basis of his great efforts, which will always be acknowledged, will be lost under the stigma of a sad history that will take him to the end of his days with a large and brilliant bureaucratic record, but with incomplete work as a composer. ${ }^{49}$

Chávez avoided responding to these accusations directly, defining himself as a worker of the "personal desires of the President of the Republic" and limiting himself to the recognition of the value of the works performed under his direction at the INBA:

I find myself working to the maximum of my capacity to realize the personal desires of the president of the Republic, and within a short time (one and a half years) of this high employee's administrative development, the Bellas Artes [INBA] is lucky to see the achievement of many things previously considered impossible to achieve..$^{50}$

In the same vein, in 1949 Chávez justified himself against critics who opposed the formalization of the musical field and his authoritarian egocentrism, by dissociating himself from the INBA project, which, in his words, was the a product of President Miguel Alemán’s initiative:

\footnotetext{
${ }^{48}$ Ibid., 397.

${ }^{49}$ Chávez, "Consideraciones sobre un calumniador," in Obras. 2, 401-13.

${ }^{50}$ Ibid., 407.
} 
Do not think that someone suggested or inspired directly or indirectly the creation the National Institute of Fine Arts to president Miguel Alemán. The interest in promoting this very important aspect of the high national culture, the name of the agency in charge of this act, the Instituto de Bellas Artes, and the central idea that governs its direction, all of these were absolutely the results of the personal and exclusive initiative of Miguel Alemán while he was still a candidate for the presidency of the Republic. ... The promotion granted to the arts by the state must be conditioned by a series of considerations. ... The formal initiative, as rightly proclaimed by the political platform of the candidate Miguel Alemán, must be directed to the creation of a national art.

The sustainability of the authoritarian Mexican regime was based, among other things, on corporatist control of the institutions and on the establishment of a permanent system of electoral fraud. Presidential power, however, was subject to a power struggle within the institutional political party (the Partido Revolucionario Institucional [PRI]). Thus, the end of a presidency signified a large turnover of senior administrators, which could bring far-reaching and important changes. In 1951, in the final years of Chávez's direction of the INBA, a group of artists formed the Bloque Nacional de Artists (National Artists Bloc), whose objective was to publicly oppose Chávez's institutional policies. Led by the composer Luis Sandi, the Bloc supported the candidacy of the future president of the Republic, Adolfo Ruiz Cortines, requesting:

1. That the arts have the highest protection of the State ...

2. That official artistic activities be reorganized in such a manner that music, dance, theater, literature, and visual arts, though related to the state, may be autonomous and permitted to develop freely.

3. That localized artistic concentration end and that art be brought systematically and continually to the entire country.

4. That artistic creation be encouraged and promoted ...

5. That a close collaboration between the State's artistic institutions and private initiatives be established.

6. That aesthetic education be assigned a correspondingly prominent role. ${ }^{51}$

The actions of the National Artists Bloc were directed mostly against Chávez and his authoritarian administration. The proposed collaboration between private initiatives and the artistic institutions of the state represented a rupture in the state model promoted by the founder of the INBA. The Bloc's position, however, affirmed the preceding role granted to the state over aesthetic education and accepted the nationalist ideological principles promoted by the state. It contested the form by which state institutions exercised power, but it did not question the aesthetic and political ideologies of those institutions. At the end of Alemán's presidency on December 1, 1952, Chávez left the direction of INBA, marking the end of three decades of holding power over the official artistic institutions in Mexico.

\footnotetext{
${ }^{51}$ Chávez, Epistolario selecto de Carlos Chávez, Series Vida y pensamiento de México, ed. Gloria Carmona (México: Fondo de Cultura Económica, 1989), 624.
} 


\section{Conclusion}

Carlos Chávez's role within the post-revolutionary regime was the result of a permanent negotiation between his own interests and various government officials. Because of the absence of stable ideological principles in the Mexican regime, Chávez constantly adapted his views. Although his nationalist discourse changed constantly, presenting profound contradictions within a decade, Chávez enjoyed relative freedom with regard to the aesthetic orientation of his own work, which he constantly adapted in response to his ties to the authoritarian Mexican regime and to musical contexts (particularly in response to critics and composers) in Mexico and the United States.

The ideological foundations of Chávez's nationalist ideal—his notion of race, his evolutionary perspective on cultures, and his teleological approach to history-present the elements of a totalitarian vision of the production, performance, and reception of art. In his conception of the political role of art, music was capable of constructing or destroying society. The relative freedom of creation that Mexican composers enjoyed was conditioned by the political needs of the state and a linear conception of historical evolution from which it was impossible to break free. Nationalism became an expression of a cultural essence that Mexico had to adopt in order to establish itself as a unity and spread its artistic genius to the world, thus contributing to the progress of humanity.

The concentration of unprecedented institutional power in the subject of fine arts, represented by the INBA, allowed the Mexican authoritarian regime, through the figure of Chávez, to exert a total control over the production and dissemination of Mexican art. That control was possible because of the absence of external, non-governmental requests for mediation and the lack of regulation of the official actions of the INBA, as well as the autocratic power of Chávez. For Chávez, however, the INBA meant a reward for his long career in the service of Mexico and constituted a vehicle to carry out the mission established three decades earlier: to build and civilize the nation through art. 